\title{
A Model for Quantification of Construction Waste in New Residential Buildings in Pearl River Delta of China
}

\author{
Liu Jingkuang*, ${ }^{*}$, Wang Yousong ${ }^{1}$ and Lin Yiyong ${ }^{1}$ \\ ${ }^{I}$ State Key Laboratory of Subtropical Architecture Science, Department of Civil Engineering, South China University of \\ Technology, Guangzhou 510640
}

\begin{abstract}
Construction waste management is currently a worldwide issue that concerns not only the on-site construction management but also the sustainable development direction of construction industry. The quantification of construction waste volume, at the project stage, is essential for the building practitioners to properly plan and control the disposal. A detailed model is established to estimate the on-site volume of construction waste for new residential buildings. This quantification model has been established based on 20 dwelling project investigations in Pearl River Delta of China. With the bill of quantities, two coefficients have been developed respectively to estimate the wreckage volume and the packaging volume. Finally, a case study of residential building with masonry-concrete structure is demonstrated to illustrate the usefulness and effectiveness of the model.
\end{abstract}

Keywords: Construction waste, Quantification model, Masonry-concrete structure, Dwelling projects

\section{INTRODUCTION}

As one of the major fixed asset formation sectors and cornerstone industries in the national economic system of China, the building industry is undergoing rapid development. Along with this process, a lot of new construction and relocation projects produce huge quantities of construction waste. Thus, on one hand, material resources are used extensively, on the other hand, the waste pollutes the ecological environment. At present, construction waste in China accounts for $30 \%-40 \%$ of total urban waste. Most of them are delivered to suburban or rural areas for simple disposal of open storage or landfill [1]. The construction waste incurs high transportation costs, as well as occupies valuable land resources. Research on this issue has just been increasing in China. Many suggested that the rapid developing building sector urgently needs sound management of construction waste [2]. However, the government has few quantitative statistic data on construction waste so far. The effective governing on construction waste is short [3]. The developers and contractors make few waste management plans, instead, they pay much more attention on maximizing economic interests their own. The careless production of construction waste, conducting a lot of illegal dumping, which bring large treatment costs for the government $[4,5]$. Therefore, it is necessary to estimate the construction waste quantity of construction projects through scientific and reasonable methods for more efficient management of the government. This paper is attempting to set up a model for quantification of construction waste in new residential buildings based on the survey data of Pearl River Delta in southern China. Moreover, a

*Address correspondence to this author at the State Key Laboratory of Subtropical Architecture Science, Department of Civil Engineering, South China University of Technology, Guangzhou 510640;

Tel: (+86)13450289815; E-mails: 1jkgowell@163.com; 57889091@qq.com case study would be empirically practiced to testify the effectiveness of the model.

\section{WASTE QUANTIFICATION PROCEDURE}

\subsection{Quantify Different Waste Streams Arising from the Construction Site}

This current work presents a method to quantify different waste streams arising from the construction site. First of all, a classification system is needed.

The classification of waste item has referenced a relevant professional standard (List of construction engineering quantity pricing norms GB50500-2008) and the classification system is hierarchic, in which the list of construction wastes are divided into different levels, such as chapters and subchapters [6].The classification code of each item is formed by 9 numbers. The numbers correspond to the main divisions of the Bill of Quantity (BOQ), called chapters, and the letters to the following divisions, called subchapters. For example, chapter 010101 refers to earth works, as sub-chapter 010101001 to earth transportation. The classification puts together similar materials, with the same measurement units.

\subsection{Determine the Quantity of each item Per Project $\left(\mathbf{Q}_{\mathrm{i}}\right)$}

These values are obtained from the measurement of 20 typical residential dwelling projects surveyed in Pearl River Delta of China Table 1. These projects have been identified by the following five main characteristics:

- Project: new construction

- Number of floors: from 1 to 10 floors, 1 or 2 basement levels and stores or offices at ground level.

- Foundation: pile, reinforced concrete slab, reinforced concrete trench or pads.

- Structure: reinforced concrete or brick walls. 
- Ceiling: inclined or horizontal.

Common characteristics are also identified in the majority of the 20 projects analyzed: $240 \mathrm{~mm} \times 115 \mathrm{~mm} \times 53 \mathrm{~mm}$ standard bricks; Wall face plastering the lime and cement mortar; Aluminous gusset plate ceiling; $400 \mathrm{~mm} \times 400 \mathrm{~mm}$ porcelain polished tiles flooring surface; Ceramic wall tiles in kitchen and bathroom; Waterproof roof paving SBS modified asphalt waterproof coiled materials.

\subsection{Estimation of Construction Waste Generation}

Once the quantities $\left(\mathrm{Q}_{\mathrm{i}}\right)$ have been determined by the surveys, the next step is to calculate the expected waste. In construction processes, two sources of waste can be defined: wreckage and packaging waste. The wreckage volume refers to the losses, off-cuts and breakage of materials during work completion, including the earth from the excavation works. The packaging waste includes material wrapping, cans, containers, pallets, etc. The proposed method allows the quantification of two kinds of waste volumes associated with the two sources of waste previously identified [7]: the Apparent Wreckage Waste Volume $\left(\mathrm{VAR}_{\mathrm{i}}\right)$ and the Apparent Packaging Waste Volume $\left(\mathrm{VAE}_{\mathrm{i}}\right)$.These two volumes derive from the Apparent Constructed Volume $\left(\mathrm{VAC}_{\mathrm{i}}\right)$.The $\mathrm{VAC}_{\mathrm{i}}$ is defined as the volume in cubic meters per square

Table 1. Category list for C\&D waste. meter built of the item "i". The unit system is that traditionally used, and all data are represented in relative values that measure the quantity of each item in $\mathrm{m}, \mathrm{m}^{2}, \mathrm{~m}^{3}, \mathrm{~kg}$ or unity per square meter built.

From the measurement of all the items identified in the building construction, the Apparent Constructed Volume is calculated using Eq. (1):

$\mathrm{VAC}_{\mathrm{i}}=\mathrm{Q}_{\mathrm{i}} \times \mathrm{CC}_{\mathrm{i}}$

where $\mathrm{VAC}_{\mathrm{i}}$ is the Apparent Constructed Volume for the item " $i$ " in $\mathrm{m}^{3} / \mathrm{m}^{2}, \mathrm{Q}_{\mathrm{i}}$ is the quantity of the item " $\mathrm{i}$ " in its specific unit $\left(\mathrm{m}, \mathrm{m}^{2}, \mathrm{~m}^{3}, \mathrm{~kg}\right.$ or unity $) / \mathrm{m}^{2}, \mathrm{CC}_{\mathrm{i}}$ is the conversion ratio of the amount of the item " $\mathrm{i}$ " in $\mathrm{VAC}$ in $\mathrm{m}^{3} / \mathrm{Q}_{\mathrm{i}}$ specific unit.

This $\mathrm{VAC}_{\mathrm{i}}$ can generate estimates on wreckage and packaging waste, depending on the kind of construction under development (new construction). Their respective volumes are calculated in Eqs. (2)-(3) using different transformation coefficients from the $\mathrm{VAC}_{\mathrm{i}}$.

In new construction projects, as far as the Apparent Wreckage Waste Volume is concerned, $\mathrm{VAR}_{\mathrm{i}}$ is calculated from the $\mathrm{VAC}_{\mathrm{i}}$ with Eq. (2):

$\mathrm{VAR}_{\mathrm{i}}=\mathrm{VAC}_{\mathrm{i}} \times \mathrm{CR}_{\mathrm{i}}=\mathrm{Q}_{\mathrm{i}} \times \mathrm{CC}_{\mathrm{i}} \times \mathrm{CR}_{\mathrm{i}}$

\begin{tabular}{|c|c|c|c|c|c|}
\hline \multicolumn{6}{|l|}{ Survey } \\
\hline \multicolumn{6}{|c|}{ Starting date: } \\
\hline \multicolumn{6}{|l|}{ Surface constructed: } \\
\hline Code & Concept & Quantity & Code & Concept & $\begin{array}{l}\text { Quan- } \\
\text { tity }\end{array}$ \\
\hline 010101001 & $\mathrm{~m}^{3}$.Excavation & & 030202001 & $\mathrm{~m}^{2}$. Radiators & \\
\hline 010101002 & $\mathrm{~m}^{3} \cdot$ Refill & & 030202002 & m. Pipes & \\
\hline 010101003 & $\mathrm{~m}^{3}$.Earthmoving transport & & 030202003 & m. Circuits & \\
\hline \multirow[t]{2}{*}{010101} & Earth works & & 030202004 & m. Derivations & \\
\hline & & & 030202005 & u. Light points & \\
\hline 010401001 & $\mathrm{Kg}$. Concrete reinforcement & & 030202006 & u. Sockets & \\
\hline 010401002 & m. Pile & & 030202007 & m. Ground connection & \\
\hline 010401003 & $\mathrm{~m}^{2}$.Commodity concrete & & 030202008 & m. Hot water pipe & \\
\hline 010401004 & $\mathrm{~m}^{3}$.Concrete & & 030202009 & u. Drains & \\
\hline 010401005 & $\mathrm{~m}^{3}$.Cast-in-situ concrete & & 030202010 & u. Tap & \\
\hline 010401006 & $\mathrm{~m}^{3}$.Concrete foundation & & 030202011 & u. Bathroom appliances & \\
\hline \multirow[t]{2}{*}{010401} & Foundation & & 030202012 & u. Thermos/heaters & \\
\hline & & & 030202 & Installations & \\
\hline 030801001 & u. Catch basins & & & & \\
\hline 030801002 & m. Collectors & & 010803001 & $\mathrm{~m}^{2}$. Acoustic insulation & \\
\hline 030801003 & m. Down pipe & & 010803002 & $\mathrm{~m}^{2}$. Thermal insulation & \\
\hline 030801 & Water disposal & & 010803 & Insulations & \\
\hline 010402001 & kg. Structural steel & & 020101001 & $\mathrm{~m}^{2}$.Tiling & \\
\hline 010402002 & $\mathrm{~m}^{2}$. Concrete slab & & 020101002 & $\mathrm{~m}^{2}$. Plaster & \\
\hline 010402003 & $\mathrm{~kg}$. Steel reinforcement & & 020101003 & $\mathrm{~m}^{2}$. Whitewash & \\
\hline
\end{tabular}


Table 1. contd....

\begin{tabular}{|c|c|c|c|c|c|}
\hline Code & Concept & Quantity & Code & Concept & $\begin{array}{l}\text { Quan- } \\
\text { tity }\end{array}$ \\
\hline 010402004 & $\mathrm{~m}^{3}$ Reinforced concrete & & 020101004 & $\mathrm{~m}^{2}$. Screed & \\
\hline 010402005 & $\mathrm{~m}^{3}$.Concrete column/beam & & 020101005 & $\mathrm{~m}^{2}$. Floors & \\
\hline \multirow[t]{2}{*}{010402} & Structures & & 020101006 & $\mathrm{~m}^{2}$. Ceiling & \\
\hline & & & 020101007 & m. Finishing & \\
\hline 010301001 & $\mathrm{~m}^{2}$. Concrete blocks & & 020101 & Tiles & \\
\hline 010301002 & $\mathrm{~m}^{2}$.Wall chambers & & & & \\
\hline 010301003 & $\mathrm{~m}^{2}$. Wall partitions & & 010503001 & $\mathrm{~m}^{2}$. Steel frames & \\
\hline 010301004 & $\mathrm{~m}^{2}$. Exterior bricks & & 010503002 & $\mathrm{~m}^{2}$. Aluminum & \\
\hline 010301005 & $\mathrm{~m}^{2}$. Interior bricks & & 010503003 & $\mathrm{~m}^{2}$. Wood & \\
\hline \multirow[t]{2}{*}{010301} & Enclosures & & 010503004 & $\mathrm{~m}^{2}$.Closet & \\
\hline & & & 010503005 & $\mathrm{~m}^{2}$. Wood doors & \\
\hline 010701001 & $\mathrm{~m}^{2}$. Horizontal roofs & & 010503006 & m. Bannister & \\
\hline 010701002 & $\mathrm{~m}^{2}$. Inclined roofs & & 010503007 & $\mathrm{~m}^{2}$. Shades & \\
\hline \multirow[t]{7}{*}{010701} & Roofs & & 010503008 & $\mathrm{~m}^{2}$. Safety bars & \\
\hline & & & 010503 & Carpentry & \\
\hline & & & 020401001 & $\mathrm{~m}^{2}$. Glass & \\
\hline & & & 020401 & Glass & \\
\hline & & & 020507001 & $\mathrm{~m}^{2}$.Exterior paint & \\
\hline & & & 020507002 & $\mathrm{~m}^{2}$.Interior paint & \\
\hline & & & 020507 & Paint & \\
\hline
\end{tabular}

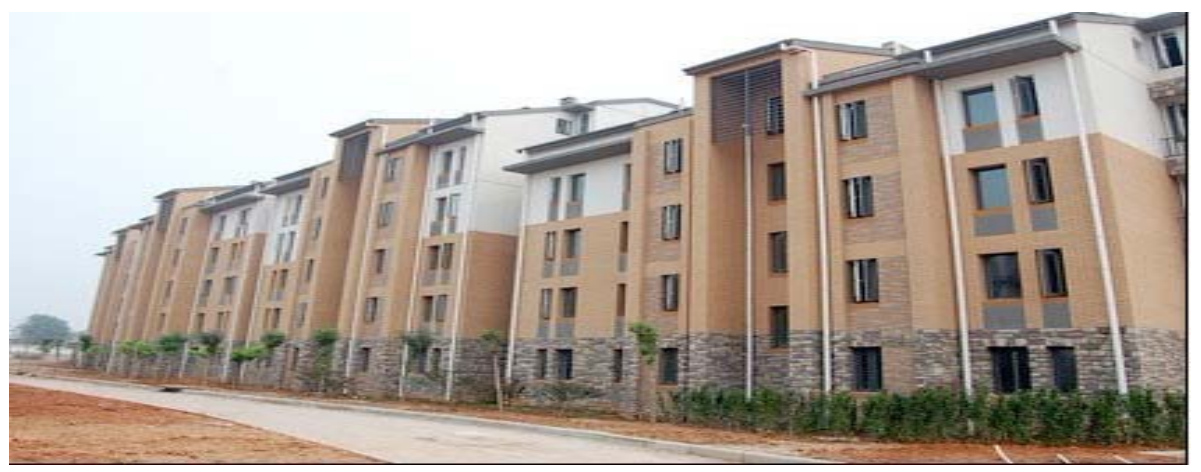

Fig. (1). Dwelling construction where the quantification model is applied in the case study.

where $\mathrm{VAR}_{\mathrm{i}}$ is the Apparent Wreckage Waste Volume for the item " $\mathrm{i}$ " in $\mathrm{m}^{3} / \mathrm{m}^{2}, \mathrm{CR}_{\mathrm{i}}$ is the coefficient for the transformation of VAC in VAR (dimensionless), namely the generation rate of Wreckage Waste.

Moreover, in new construction projects, the Apparent Packaging Waste Volume is estimated from the $\mathrm{VAC}_{\mathrm{i}}$ using Eq. (3):

$\mathrm{VAE}_{\mathrm{i}}=\mathrm{VAC}_{\mathrm{i}} \times \mathrm{CE}_{\mathrm{i}}=\mathrm{Q}_{\mathrm{i}} \times \mathrm{CC}_{\mathrm{i}} \times \mathrm{CE}_{\mathrm{i}}$

where $\mathrm{VAE}_{\mathrm{i}}$ is the Apparent Packaging Waste Volume for the item " $\mathrm{i}$ " in $\mathrm{m}^{3} / \mathrm{m}^{2}, \mathrm{CE}_{\mathrm{i}}$ is the coefficient transforma- tion of VAC in VAE (dimensionless), namely the generation rate of Packaging Waste.

The final step to estimate the waste volume $\left(\mathrm{m}^{3}\right)$ of a new construction project is to add the result of multiplying the Apparent Wreckage Waste Volume $\left(\mathrm{m}^{3} / \mathrm{m}^{2}\right)$ and the Apparent Packaging Waste Volume $\left(\mathrm{m}^{3} / \mathrm{m}^{2}\right)$ by the building surface $\left(\mathrm{m}^{2}\right)$.

Since Chinese government does not have enacted official statistics data, these coefficients, $\mathrm{CC}_{\mathrm{i}}$ and $\mathrm{CE}_{\mathrm{i}}$, are obtained from Jaime Solis-Guzman et al., (2009) and the investiga 
Table 2. Estimation of the waste volume expected in a new construction project. Type: new construction building Usage: Dwellings Floor numbers: 4 Total surface: $1650 \mathrm{~m}^{2} \quad$ Foundation type: Piles up to $8.00 \mathrm{~m}$. Structure: Reinforced concrete Roof: Horizontal

\begin{tabular}{|c|c|c|c|c|c|c|c|c|c|c|c|}
\hline Code & Concept & $\mathbf{Q}_{\mathrm{i}}$ & $\mathrm{CC}_{\mathrm{i}}{ }^{\mathrm{a}}$ & $\mathbf{C R}_{\mathrm{i}}{ }^{\mathrm{b}}$ & $\mathbf{C E}_{\mathrm{i}}^{\mathrm{c}}$ & $\mathbf{V A C}_{i}$ & $\mathbf{V A R}_{\mathbf{i}}$ & $\mathbf{V A E}_{i}$ & $\begin{array}{l}\mathrm{m}^{3} \text { Was- } \\
\text { te per } \mathrm{m}^{2}\end{array}$ & $\begin{array}{l}\mathbf{m}^{3} \\
\text { Waste } \\
/ 1650 \\
\mathbf{m}^{2}\end{array}$ & $\begin{array}{l}\text { Per- } \\
\text { centa- } \\
\text { ge }\end{array}$ \\
\hline 010101003 & $\begin{array}{l}\mathrm{m}^{3} . \text { Earthmoving } \\
\text { transport }\end{array}$ & 0.21 & 1.0000 & 1.0000 & 0.0000 & 0.2100 & 0.2100 & 0.0000 & 0.2100 & 346.50 & 0.62 \\
\hline 010401001 & $\begin{array}{l}\mathrm{kg} . \text { Concrete } \\
\text { reinforcement }\end{array}$ & 5.12 & 0.0001 & 0.0204 & 0.0000 & 0.0005 & 0.0000 & 0.0000 & 0.0000 & 0.02 & 0.00 \\
\hline 010401002 & m. Pile & 0.26 & 0.3200 & 0.0800 & 0.0000 & 0.0832 & 0.0067 & 0.0000 & 0.0067 & 10.98 & 0.02 \\
\hline 010401004 & $\mathrm{~m}^{3}$.Concrete & 0.08 & 1.0000 & 0.0300 & 0.0000 & 0.0800 & 0.0024 & 0.0000 & 0.0024 & 3.96 & 0.01 \\
\hline 010401003 & $\begin{array}{l}\mathrm{m}^{3} . \text { Commodity } \\
\text { concrete }\end{array}$ & 0.02 & 1.0000 & 0.0134 & 0.0000 & 0.0200 & 0.0003 & 0.0000 & 0.0003 & 0.44 & 0.00 \\
\hline 010401006 & $\begin{array}{l}\mathrm{m}^{3} . \text { Concrete } \\
\text { foundation }\end{array}$ & 0.04 & 1.0000 & 0.0300 & 0.0000 & 0.0400 & 0.0012 & 0.0000 & 0.0012 & 1.98 & 0.00 \\
\hline 030801001 & u. Catch basins & 0.02 & 0.3800 & 0.0500 & 0.0500 & 0.0076 & 0.0004 & 0.0004 & 0.0008 & 1.25 & 0.00 \\
\hline 030801002 & m. Collectors & 0.06 & 0.0830 & 0.0600 & 0.0100 & 0.0050 & 0.0003 & 0.0000 & 0.0003 & 0.58 & 0.00 \\
\hline 030801003 & m. Down pipe & 0.11 & 0.0140 & 0.0100 & 0.0200 & 0.0015 & 0.0000 & 0.0000 & 0.0000 & 0.08 & 0.00 \\
\hline 010402002 & $\mathrm{~m}^{2}$. Concrete slab & 1.24 & 0.2800 & 0.0400 & 0.0200 & 0.3472 & 0.0139 & 0.0069 & 0.0208 & 34.37 & 0.06 \\
\hline 010402003 & $\begin{array}{l}\mathrm{kg} . \text { Steel } \\
\text { reinforcement }\end{array}$ & 13.42 & 0.0001 & 0.0200 & 0.0000 & 0.0013 & 0.0000 & 0.0000 & 0.0000 & 0.04 & 0.00 \\
\hline 010402005 & $\begin{array}{l}\mathrm{m}^{3} \text {.Concrete } \\
\text { column/beam }\end{array}$ & 0.24 & 1.0000 & 0.0300 & 0.0000 & 0.2400 & 0.0072 & 0.0000 & 0.0072 & 11.88 & 0.02 \\
\hline 010301001 & $\begin{array}{l}\mathrm{m}^{2} \text {.Concrete } \\
\text { blocks }\end{array}$ & 0.84 & 0.0500 & 0.0360 & 0.1000 & 0.0420 & 0.0015 & 0.0042 & 0.0057 & 9.42 & 0.02 \\
\hline 010301003 & $\begin{array}{l}\mathrm{m}^{2} . . \text { Wall partiti- } \\
\text { ons }\end{array}$ & 0.86 & 0.0500 & 0.0560 & 0.1000 & 0.0430 & 0.0024 & 0.0043 & 0.0067 & 11.07 & 0.02 \\
\hline 010301004 & $\begin{array}{l}\mathrm{m}^{2} \text {. Exterior } \\
\text { bricks }\end{array}$ & 0.99 & 0.1400 & 0.0300 & 0.1000 & 0.1386 & 0.0042 & 0.0139 & 0.0180 & 29.73 & 0.05 \\
\hline 010301005 & $\begin{array}{l}\mathrm{m}^{2} . \text { Interior } \\
\text { bricks }\end{array}$ & 0.45 & 0.1400 & 0.0300 & 0.1000 & 0.0630 & 0.0019 & 0.0063 & 0.0082 & 13.51 & 0.02 \\
\hline 010701002 & $\mathrm{~m}^{2}$. Inclined roofs & 0.68 & 0.1800 & 0.0610 & 0.0300 & 0.1224 & 0.0075 & 0.0037 & 0.0111 & 18.38 & 0.03 \\
\hline 030202003 & m. Circuits & 0.83 & 0.0002 & 0.0100 & 0.5000 & 0.0002 & 0.0000 & 0.0001 & 0.0001 & 0.14 & 0.00 \\
\hline 030202004 & m. Derivations & 0.16 & 0.0003 & 0.0100 & 0.5000 & 0.0000 & 0.0000 & 0.0000 & 0.0000 & 0.04 & 0.00 \\
\hline 030202005 & u. Light points & 0.12 & 0.0012 & 0.0100 & 1.0000 & 0.0001 & 0.0000 & 0.0001 & 0.0001 & 0.24 & 0.00 \\
\hline 030202006 & u. Sockets & 0.23 & 0.0012 & 0.0100 & 1.0000 & 0.0003 & 0.0000 & 0.0003 & 0.0003 & 0.46 & 0.00 \\
\hline 030202007 & $\begin{array}{l}\text { m.Ground con- } \\
\text { nection }\end{array}$ & 0.13 & 0.0006 & 0.0100 & 0.5000 & 0.0001 & 0.0000 & 0.0000 & 0.0000 & 0.07 & 0.00 \\
\hline 030202008 & $\begin{array}{l}\mathrm{m} . \text { Hot water } \\
\text { pipe }\end{array}$ & 0.32 & 0.0006 & 0.0100 & 0.0000 & 0.0002 & 0.0000 & 0.0000 & 0.0000 & 0.00 & 0.00 \\
\hline 030202009 & u. Drains & 0.06 & 0.0140 & 0.0100 & 0.2000 & 0.0008 & 0.0000 & 0.0002 & 0.0002 & 0.29 & 0.00 \\
\hline 0302020010 & u. Tap & 0.08 & 0.0038 & 0.0000 & 1.0000 & 0.0003 & 0.0000 & 0.0003 & 0.0003 & 0.50 & 0.00 \\
\hline
\end{tabular}


Table 2. contd....

\begin{tabular}{|c|c|c|c|c|c|c|c|c|c|c|c|}
\hline Code & Concept & $\mathbf{Q}_{\mathbf{i}}$ & $\mathrm{CC}_{\mathrm{i}}^{\mathrm{a}}$ & $\mathbf{C R}_{\mathrm{i}}{ }^{\mathrm{b}}$ & $\mathbf{C E}_{\mathrm{i}}^{\mathrm{c}}$ & $\mathbf{V A C}_{i}$ & $\mathbf{V A R}_{\mathbf{i}}$ & $\mathbf{V A E}_{\mathrm{i}}$ & $\begin{array}{l}\mathrm{m}^{3} \text { Was- } \\
\text { te per } \mathrm{m}^{2}\end{array}$ & $\begin{array}{l}\mathrm{m}^{3} \\
\text { Waste } \\
/ 1650 \\
\mathbf{m}^{2}\end{array}$ & $\begin{array}{l}\text { Per- } \\
\text { centa- } \\
\text { ge }\end{array}$ \\
\hline 030202011 & $\begin{array}{l}\text { u.Bathroom } \\
\text { appliances }\end{array}$ & 0.07 & 0.1830 & 0.0200 & 0.2500 & 0.0128 & 0.0003 & 0.0032 & 0.0035 & 5.71 & 0.01 \\
\hline 030202012 & $\begin{array}{l}\text { u. Ther- } \\
\text { mos/heaters }\end{array}$ & 0.01 & 0.2600 & 0.0000 & 0.0500 & 0.0026 & 0.0000 & 0.0001 & 0.0001 & 0.21 & 0.00 \\
\hline 010803002 & $\begin{array}{l}\mathrm{m}^{2} \text {. Thermal } \\
\text { insulation }\end{array}$ & 0.78 & 0.0360 & 0.0100 & 0.0000 & 0.0281 & 0.0003 & 0.0000 & 0.0003 & 0.46 & 0.00 \\
\hline 020101001 & $\mathrm{~m}^{2}$.Tiling & 0.52 & 0.0320 & 0.0398 & 0.5000 & 0.0166 & 0.0007 & 0.0083 & 0.0090 & 14.82 & 0.03 \\
\hline 020101002 & $\mathrm{~m}^{2}$.Plaster & 1.84 & 0.0290 & 0.0300 & 0.0000 & 0.0534 & 0.0016 & 0.0000 & 0.0016 & 2.64 & 0.00 \\
\hline 020101003 & $\mathrm{~m}^{2}$.Whitewash & 4.12 & 0.0250 & 0.0300 & 0.0000 & 0.1030 & 0.0031 & 0.0000 & 0.0031 & 5.10 & 0.01 \\
\hline 020101004 & $\mathrm{~m}^{2}$. Screed & 0.86 & 0.0830 & 0.0500 & 0.0500 & 0.0714 & 0.0036 & 0.0036 & 0.0071 & 11.78 & 0.02 \\
\hline 020101005 & $\mathrm{~m}^{2}$.Floors & 0.12 & 0.2100 & 0.0300 & 0.1000 & 0.0252 & 0.0008 & 0.0025 & 0.0033 & 5.41 & 0.01 \\
\hline 020101006 & $\mathrm{~m}^{2}$.Ceiling & 0.14 & 0.0510 & 0.0500 & 0.2000 & 0.0071 & 0.0004 & 0.0014 & 0.0018 & 2.95 & 0.01 \\
\hline 020101007 & $\mathrm{~m}$. Finishing & 0.15 & 0.0190 & 0.0500 & 0.1000 & 0.0029 & 0.0001 & 0.0003 & 0.0004 & 0.71 & 0.00 \\
\hline 010503001 & $\mathrm{~m}^{2}$. Steel frames & 0.12 & 0.0530 & 0.0000 & 0.0500 & 0.0064 & 0.0000 & 0.0003 & 0.0003 & 0.52 & 0.00 \\
\hline 010503005 & $\mathrm{~m}^{2}$. Wood doors & 0.18 & 0.0530 & 0.0600 & 0.1000 & 0.0095 & 0.0006 & 0.0010 & 0.0015 & 2.52 & 0.00 \\
\hline 010503007 & $\mathrm{~m}^{2}$.Shades & 0.10 & 0.0620 & 0.0200 & 0.0500 & 0.0062 & 0.0001 & 0.0003 & 0.0004 & 0.72 & 0.00 \\
\hline 020401001 & $\mathrm{~m}^{2}$.Glass & 0.16 & 0.0120 & 0.0500 & 0.5000 & 0.0019 & 0.0001 & 0.0010 & 0.0011 & 1.74 & 0.00 \\
\hline 020507001 & $\begin{array}{l}\mathrm{m}^{2} \text {.Exterior } \\
\text { paints }\end{array}$ & 0.26 & 0.0053 & 0.0500 & 1.5000 & 0.0014 & 0.0001 & 0.0021 & 0.0021 & 3.52 & 0.01 \\
\hline \multirow[t]{2}{*}{020507002} & $\mathrm{~m}^{2}$.Interior paints & 0.57 & 0.0052 & 0.0500 & 1.5000 & 0.0030 & 0.0001 & 0.0044 & 0.0046 & 7.58 & 0.01 \\
\hline & Total & & & & & 1.7988 & 0.2715 & 0.0693 & 0.3076 & 562.33 & 1.00 \\
\hline
\end{tabular}

${ }^{\text {a }}$ Data obtained from Jaime Solis-Guzman et al. (2009) [7] and the investigation data on construction waste from Pearl River Delta Region of China

${ }^{\mathrm{b}}$ Data obtained from the book "Standard quantity of Shenzhen building works consumed(2003)"[8]

${ }^{\mathrm{c}}$ Data obtained from Jaime Solis-Guzman et al. (2009) [7] and the investigation data on construction waste in Pearl River Delta Region of China.

tion data on construction waste in Pearl River Delta Region.

$\mathrm{CR}_{\mathrm{i}}$ is estimated from the attrition rate of building materials in the book "Standard quantity of Shenzhen building works consumed (2003)" [8]. In the next section some coefficient determinations are described.

\section{CASE STUDY}

The following examples apply the quantification model to a new construction (Table 2). The example is a dwelling project with the following main group characteristics Fig. (1) apartment building of four floors, a structure formed by reinforced concrete columns, beams and a pile foundation of less than $8 \mathrm{~m}$ deep, and horizontal ceiling. The total surface of the building is $1650 \mathrm{~m}^{2}$.

In Table 2, the three conversion parameters $\left(\mathrm{CC}_{\mathrm{i}}, \mathrm{CR}_{\mathrm{i}}\right.$ and $\mathrm{CE}_{\mathrm{i}}$ ), applied when considering the construction of this dwelling project, can be observed. For example, in subchapter 010101001, Earthmoving transport, the item quantity for this specific type of construction is $0.20 \mathrm{per} \mathrm{m}^{3} / \mathrm{m}^{2}$ constructed. The soil from the excavation is already defined in volume units, as cubic meters of loose soil, subsequently the conversion ratio $\mathrm{CC}_{\mathrm{i}}$ is 1 . The next coefficient listed, $\mathrm{CR}_{\mathrm{i}}$, is 1 since all the earth excavated is sent to the landfill. Finally, $\mathrm{CE}_{\mathrm{i}}$ is 0 because the soil needs no packaging.

A second example in Table 2, sub-chapter 010503005, wood doors, the item quantity in the project analyzed is 0.18 per $\mathrm{m}^{2} / \mathrm{m}^{2}$ constructed. In this sub-chapter, the item measurement unit is $\mathrm{m}^{2}$, and to translate it into a constructed volume, $\mathrm{CC}_{\mathrm{i}}$ is 0.05 per $\mathrm{m}^{3} / \mathrm{m}^{2}$, which is due to the fact that a typical door thickness is $5 \mathrm{~cm}$. A similar analysis is performed for each sub-chapter. The following coefficient, $\mathrm{CR}_{\mathrm{i}}$, is 0.02 . This value is obtained from the attrition rate of building materials in the book "Standard quantity of Shenzhen building works consumed (2003)" [8]. Finally, $\mathrm{CE}_{\mathrm{i}}$ is 0.10 since the door packaging is approximately $10 \%$ of the door volume.

By multiplying the Apparent Wreckage Waste Volume and the Apparent Packaging Waste Volume of each item by the building surface $\left(1650 \mathrm{~m}^{2}\right)$, the expected waste volume can be estimated in the new construction analysis. To sum up, Table 2 predicts $562.33 \mathrm{~m}^{3}$ total wastes, $346.50 \mathrm{~m}^{3}$ is excavated soil and $215.83 \mathrm{~m}^{3}$ is mixed waste (including pack- 
aging). Calculations showed a waste generation of 0.34 $\mathrm{m}^{3} / \mathrm{m}^{2}$ (Soil is considered) for the new construction projects and generate the biggest volume are soil, concrete and bricks. The soil is part of group 10101003, earthmoving transport; and the concrete is part of several groups in chapters $010401(10401004,10401003,10401006)$ and 010402 $(10402002,10402005)$ and the bricks belong to chapter 010301 (10301001, 10301004, 10301005). These three items constitute about $80 \%$ of the total waste volume.

The soil can easily be reused for refilling on the same construction site or for other work. The concrete and bricks can also be used as refilling for pipelines, roads or walking tracks at the same site, or treated to be reused on a different site.

\section{CONCLUSION}

The rapid development of urbanization brings a lot of new construction projects, which produce huge construction waste in China. However, most of the waste is simply dumped without proper treatment or control. This incurs serious environmental pollution problems. The Chinese government is trying to set up a comprehensive legislation system to guide the macro-economy, including construction industry, into sustainable process. The construction waste of construction projects should be life-cycle managed, namely, from design phase to completion and usage phase, even to demolition phase. All participants of construction projects are obligated to go through "Reduce, Reuse, and Recycle" procedures.

This paper established a convenient quantification model of construction waste for practice. The calculation method of this model is simple due to the same code number with construction quantity of bill. For the last two years the model has been testified at the dwelling projects in Pearl River Delta of China. The accuracy is about $85 \%$ between theoretical and practical. Developers can budget the treatment costs of construction waste by estimating the volume of possible construction waste. The government could promote a commercial market waste operation with appropriate compensation to the developers and contractors.

The quantification construction waste is one of the first steps to achieve the sustainable development goal [9]. Accurate forecast of the construction waste volume can help to enhance management level in the industry, as well as to reduce the waste produced during the construction process [10, 11]. At present this quantification model mainly aims at the buildings with multi-layer masonry-concrete structures. The buildings with other structural and functional styles would be demonstrated in the future. In addition, the study regions could be spread from the Pearl River Delta to other part of China.

\section{CONFLICT OF INTEREST}

The authors confirm that this article content has no conflicts of interest.

\section{ACKNOWLEDGEMENT}

Authors are thankful to the State Key Laboratory of Subtropical. Architecture Science, South China University of Technology (Independent Research Project "Cost compensating econometric model theory and application research on waste disposal of construction project.' Project No. $\mathrm{x} 2 \mathrm{tjC7100870)}$ for providing financial support to this research.

\section{REFERENCES}

[1] P. Li, "Comprehensively utilize construction waste and vigorously develop economic cycle", Practice and Theory of Sezs, vol. 06, pp. 84-91, 2007. (in Chinese).

[2] W.H. Lu, H.P. Yuan, J.R. Li, Jane J.L. Hao, X.M. Mi, and Z.K. Ding, "An empirical investigation of construction and demolition waste generation rates in Shenzhen city, South China", Waste Management, vol. 31, pp. 680-687, 2011.

[3] J.K. Liu, and Y.S. Wang, "Establishment and application of performance assessment model of waste management in architectural engineering projects in China", Journal of Systems Engineering Procedia, vol. 4, pp. 147-155, 2011.

[4] J.R. Li, and J.Y. Wang, "Investigation and analysis on generation level of construction waste for new projects", Construction Economy, vol. 01, pp. 83-86, 2010. (in Chinese).

[5] J.R. Li, Z.K. Ding, X.M. Mi, and J.Y. Wang "Analysis on influence factors of construction waste generation level", Journal of Huazhong University of Science and Technology (Urban Science), vol. 27, no. 3, pp. 39-42, 2010. (in Chinese).

[6] Ministry of Housing and Urban-Rural Developmen.Standard of valuation of detailed list of volume of construction project (GB50500-2008). China Plan Publishing Company, Beijing, 2008. (in Chinese).

[7] J. Solis-Guzman, "A Spanish model for quantification and management of construction waste", Waste Management, vol. 29, pp. 2542-2548, 2009.

[8] The office of Shenzhen Construction Cost Management .Standard quantity of Shenzhen building works consumed (2003). Publishing House of the intellectual property in China, Beijing, 2004. (in Chinese) .

[9] C. Llatas, "A model for quantifying construction waste in projects according to the European waste list", Waste Management, vol. 31, pp. 1261-1276, 2011.

[10] A. Katz, and H. Baum, "A novel methodology to estimate the evolution of construction waste in construction sites", Waste Management, vol. 31, pp. 353-358, 2011.

[11] P.V. Sáez, M. del Río, and C. Porras-Amores, "Estimation of construction and demolition waste volume generation in new residential buildings in Spain", Waste Management and Research, vol. 11, pp. 1-10, 2011. 